\title{
Justiça Eleitoral Contramajoritária e Soberania Popular: a democrática vontade das urnas e a autocrática vontade judicial que a nulifica
}

\author{
Ruy Samuel Espíndola ${ }^{1}$ (UFSC, Brasil) \\ ruysamuel@hotmail.com \\ Rua Felipe Schmidt, 249 - Edifício ARS - Sala 503 \\ Florianópolis /SC - CEP 88.010-902
}

\footnotetext{
1. Membro da Academia Catarinense de Letras Jurídicas, cadeira de n. 14, patrono Advogado Acácio Bernardes - Membro fundador da Academia Catarinense de Direito Eleitroal. Professor de Direito Constitucional da Escola Superior de Magistratura de Santa Catarina e Professor de Direito Eleitoral da ESA/ $\mathrm{OAB} / \mathrm{SC}$ e ESA/OAB/PI - Mestre em Direito Público pela UFSC - Autor do livro "Conceito de Princípios Constitucionais", RT, 2 ed. - Conferencista Internacional - Membro Consultor da Comissão Nacional de Estudos Constitucionais do Conselho Federal da OAB - Membro da Comissão de Direito Constitucional do Conselho Seccional da OAB/SC - Sócio gerente da Espíndola \& Valgas, Advogados Associados, com sede em Florianópolis/SC - Advogado militante perante o TSE e STF - ruysamuel@hotmail.com e www.espindolaevalgas.com.br.
} 


\title{
Resumo
}

O presente ensaio objetiva refletir, em termos críticos, sobre o crescente avanço da jurisdição eleitoral sobre a vontade das urnas e sobre os direitos políticos de votar e ser votado. Avanço ampliado, especialmente, pela legislação eleitoral dos últimos anos (da lei ordinária 9.840/99, que instituiu o 41-A à lei complementar n. 135/210, "ficha limpa"). Sobretudo, objetiva refletir sobre o papel contramajoritário da Justiça eleitoral ao invalidar o resultado de eleições de candidatos eleitos ou mandatários empossados, tendo em conta decisóes que cassam ou indeferem registros, diplomas ou mandatos.

Palavras-chave: Soberania, Democracia, Processo Eleitoral, Constitucionalidade

\begin{abstract}
This essay presents some critical reflections on the growing encroachment of the jurisdiction of the electoral courts over the will expressed at the polls and the rights to vote and run for office. This has mainly been prompted in recent years with the enactment of Law 9,840/99, which added Article 41-A to Complementary Law 135/2010 (the so-called "Clean Record Law" regarding eligibility to run for public office). The principal objective is to reflect on the countermajority character of the electoral courts when they invalidate the results of elections or remove elected officials from office due to past acts.
\end{abstract}

Keywords: Sovereignty, democracy, electoral procedural law, constitutionality. 
O presente ensaio objetiva refletir, em termos críticos, sobre o crescente avanço da jurisdição eleitoral sobre a vontade das urnas e sobre os direitos políticos de votar e ser votado. Avanço ampliado, especialmente, pela legislação eleitoral dos últimos anos (da lei ordinária 9.840/99, que instituiu o 41-A à lei complementar n. 135/210, "ficha limpa"). Sobretudo, objetiva refletir sobre o papel contramajoritário da Justiça eleitoral ao invalidar o resultado de eleiçóes de candidatos eleitos ou mandatários empossados, tendo em conta decisões que cassam ou indeferem registros, diplomas ou mandatos.

\section{II}

Ao procurar tutelar as liberdades de votar e a liberdade de postular votos para ocupação e exercício de mandatos populares, a justiça eleitoral deve sempre proteger, igualmente, os direitos políticos fundamentais dos cidadãos: (i) cidadãos alistados para votar e (ii) cidadãos filiados partidariamente, que, aprovados em convenções partidárias, resolvem pedir ao Judiciário eleitoral que lhes defira o direito de disputarem mandato político para os cargos eletivos existentes na República.

Para votar, lembremos, é necessário o preenchimento das condiçôes de alistabilidade (artigos $4^{\circ}$ e $5^{\circ}$ do Código Eleitoral ${ }^{2}$ e $14, \S 1^{03}$ Constituição Federal). Para receber votos, para pedir candidatura, é necessário demonstrar as condições de elegibilidade e não apresentar causas de incompatibilidades ou inelegibilidades. Essas últimas são causas impeditivas de candidaturas, e podem ser contemporâneas ou posteriores ao pedido de registro (artigo $3^{04}$ do CE e $14, \S 3^{05} \mathrm{CF}$ ).

2."Art. 4 São eleitores os brasileiros maiores de 18 anos que se alistarem na forma da lei. (norma alterada pelo art. 14 da Constituição Federal)

Art. $5^{\circ}$ Não podem alistar-se eleitores: I - os analfabetos; (norma alterada pelo art. $14, \S 1^{\circ}$, II, “a”, da Constituição/88) II - os que no saibam exprimir-se na língua nacional; III - os que estejam privados, temporária ou definitivamente dos direitos políticos. Parágrafo único - Os militares são alistáveis, desde que oficiais, aspirantes a oficiais, guardas-marinha, subtenentes ou suboficiais, sargentos ou alunos das escolas militares de ensino superior para formação de oficiais."

3.“ $\$ 1^{\circ}$ - O alistamento eleitoral e o voto são: I - obrigatórios para os maiores de dezoito anos; II - facultativos para: a) os analfabetos; b) os maiores de setenta anos; c) os maiores de dezesseis e menores de dezoito anos."

4. "Art. $3^{\circ}$ Qualquer cidadão pode pretender investidura em cargo eletivo, respeitadas as condições constitucionais e legais de elegibilidade e incompatibilidade."

5." $\$ 3^{\circ}$ - São condiçóes de elegibilidade, na forma da lei: I - a nacionalidade brasileira; II - o pleno exercício dos direitos políticos; III - o alistamento eleitoral; IV - o domicílio eleitoral na circunscrição; V - a filiação partidária; VI - a idade mínima de: a) trinta e cinco anos para Presidente e Vice-Presidente da República e Senador; b) trinta anos para Governador e Vice-Governador de Estado e do Distrito Federal; c) vinte e um anos para Deputado Federal, Deputado Estadual ou Distrital, Prefeito, Vice-Prefeito e juiz de paz; d) dezoito anos para Vereador." 
Para o exercício da soberania popular - princípio estruturante do sistema constitucional vigente - a junção dessas duas liberdades é fundamental. Ou seja, a junção dos direitos de votar e o de ser votado. Mesmo o Código Eleitoral, produzido em plena ditadura militar, em 15.07.65, parece ter percebido a riqueza desses dois direitos políticos em seu artigo primeiro: "Este Código contém normas destinadas a assegurar a organização e o exercício de direitos políticos, precipuamente os de votar e ser votado."

\section{III}

A soberania popular se exterioriza pelo voto direto, secreto, universal e periódico ${ }^{6}$, manifestado nas urnas - hoje urnas eletrônicas. A vontade dos cidadãos representados, elegendo seus representantes políticos - os candidatos - é momento instituinte de mandatos, de investidura de cargos eletivos ${ }^{7}$, e de eleição de planos de governo e propostas partidárias (ao menos em tese, assim o faz o eleitor, na urna). Momento que se aproxima do momento constituinte, mas não o supera em relevância jurídica e política; do momento supremo de feitura de nova Constituição.

Vontade constituinte e vontade instituinte nas urnas são "vontades base", "vontades chaves", que se realizam em momentos inaugurais para o Direito, no caso da vontade constituinte; e reiniciais para a continuidade da política representativa, no caso da vontade das urnas, sendo esta periodicamente renovável.

Se a primeira, a vontade constituinte, é momento que objetiva perenidade e permanência diretiva; a vontade das urnas é extensão e renovação da primeira; a vontade das urnas é assegurada e limitada pela vontade constituinte. A vontade das urnas, assim, é vontade fruto de um poder constituído, o povo (que também é o titular do poder constituinte), do corpo de eleitores e do corpo de candidatos. Todavia, ambas, são vontades chaves de uma democracia constitucional $^{8}$ : vontade constituinte - fundante e inaugural -, e vontade das urnas - renovadora e continuadora da obra feita pelo poder constituinte.

Essa vontade renovadora, instituída pelas urnas, realiza a vontade direta dos eleitores, ao manifestarem decisão sobre quem eles querem que lhes represente na feitura de leis e demais atos de estado comportados nas funçóes executivas e legislativas pertinentes. Lembrando que entre nós, os juízes não são eleitos por sufrágio popular9.

6. Afirma a Constituição da República, em seu artigo 14: "A soberania popular será exercida pelo sufrágio universal e pelo voto direto e secreto, com valor igual para todos (...)".

7. Prescreve o Código Eleitoral em seu art. 20: "Todo poder emana do povo e será exercido em seu nome, por mandatários escolhidos, direta e secretamente, dentre candidatos indicados por partidos políticos nacionais, ressalvada a eleição indireta nos casos previstos na Constituição e leis específicas."

8. Sobre nossa concepção de democracia constitucional, ver nosso artigo: A Constituição como Garantia da Democracia: o papel dos Princípios Constitucionais. Revista de Direito Constitucional e Internacional. Cadernos de Direito Constitucional e Ciência Política. São Paulo: Revista dos Tribunais/Instituto Brasileiro de Direito Constitucional, ano 11, abr./jun. 2003, n. 44, p 75/86. E sobre democracia representativa em contraponto a democracia participativa, ver também nosso artigo Democracia Participativa: auto-convocação de referendos e plebiscitos pela população. Estudos Eleitorais, Brasília, TSE, v. 5, n. 2, mai/ago 2010, p. 65/87.

9. Conforme a CF, artigo 93, inciso I: "ingresso na carreira, cujo cargo inicial será o de juiz substituto, mediante concurso público de provas e títulos (...)." 
São vontades eleitorais, "vontades das urnas", as manifestadas nas diferentes unidades da federação, para realizar o autogoverno dessas pessoas políticas federadas: na União, para prover os mandatos de Presidente, Vice-Presidente, Senadores e Deputados Federais; nos Estados-Membros, para mandatos de Deputados Estaduais e Governadores e Vice-Governadores; nos Municípios, para a representação política de Prefeito, Vice-Prefeito e Vereadores.

Essas vontades populares eletivas, nas unidades federadas, são fruto da junção calculada de vontades do eleitor e vontades dos candidatos e partidos políticos ou coligaçóes partidárias, respectivamente. Assim, é possivel afirmar que não há vontade popular apenas com o voto do eleitor, embora seja este o maior protagonista do processo eleitoral. A vontade eleitoral, que escolhe, elege os representantes, é fruto de atuação coadjuvada entre eleitores, candidatos e partidos políticos ou coligações partidárias correspectivas ${ }^{10}$.

Em termos cronológicos e lógicos, no âmbito do processo eleitoral, a vontade de candidatos e partidos políticos, precede a vontade do eleitor. Ou seja, a vontade do eleitor é antecedida pela vontade do candidato, então filiado partidariamente.

O candidato dever ser regularmente domiciliado e inscrito em determinada zona eleitoral, submetendo seu nome às convenções partidárias, órgãos de manifestação da vontade de partidos políticos.

Os partidos políticos, pós-convenções, vão buscar na justiça eleitoral inscrição de candidaturas e proteção para as mesmas, tanto no que toca ao deferimento do registro, quanto à concretização de sua propaganda eleitoral para fins de êxito na empreitada, senão do candidato em si, mas do partido ao qual esteja filiado (isso, especialmente, no sistema de eleição proporcional, que se dá para Deputados Federais e Estaduais, assim como Vereadores).

Assim, quando o eleitor vota, na urna eletrônica, manifestando sua vontade, o seu querer foi associado ao querer daquele candidato que manifestou sua vontade em filiar-se a partido, e a este partido, que, com a vontade de sua convenção, referendou o querer do candidato para, juntos (partido e candidato), apresentarem opção de escolha válida ao eleitor. Deste modo, segundo nossa ordem jurídica, a vontade popular é um somatório processual e quantitativo de vontades concorrentes: $a$ vontade do candidato, a vontade de seu partido político e a vontade dos eleitores que apostaram em ambos.

É nessa perspectiva que devemos entender a assegurabilidade, até mesmo contra reformas inconstitucionais da Constituição, do voto direto, secreto, universal e periódico ${ }^{11}$. O voto como manifestação complexa, em junção de vontades, para manifestar a soberania popular: vontade manifestada pelo querer do eleitor, do candidato e de seu partido.

10. Afirma a Lei dos Partidos Políticos, Lei 9.096, de 19.09.95: "Art. 18. Para concorrer a cargo eletivo, o eleitor deverá estar filiado ao respectivo partido pelo menos um ano antes da data fixada para as eleições, majoritárias ou proporcionais."

11. Preceito da Constituição da República: “Art. 60. A Constituição poderá ser emendada (...) § $4^{\circ}$ - Não será objeto de deliberação a proposta de emenda tendente a abolir: (...). II - o voto direto, secreto, universal e periódico." 
Assim, tendo em conta essa premissa teórica, é lícito concluir: a anulação de uma eleição, resultante da cassação de um registro após as eleiçôes ou a cassação de um diploma conferido ao eleito, ou mesmo de um mandato, jamais são a mera obstaculização de uma liberdade política individualmente considerada; o cerceamento atomizado do direito político de um único cidadão, acidentalmente candidato; a mera privação de uma vontade individual e solitária, manifestada em dissociação e sem concorrência de outras vontades. Não e não! Equivoco manifesto carrega a visão que vislumbra somente a liberdade politica de receber votos como afetada na hipótese!

Cassar um registro, um diploma, um mandato, é cassar o conjunto de vontades que convergiram para que pudéssemos falar em vontade popular, em soberania popular, cujo cerne, insistamos, está na vontade dos eleitores, em número próprio a eleger candidatos inscritos por determinados partidos ou coligações partidárias. E isso é razoável dizer mesmo que não tenha ainda chegado o dia da eleição e o registro do candidato tenha sido cerceado antes do escrutínio: por que há pesquisas eleitorais, aferição da intenção popular de voto, que integra o grande processo eleitoral e demonstra as expectativas de sufrágio do eleitor.

Destarte, somente por uma fição, um grande equivoco e um sério olvido do valor dos direitos-liberdades de votar e de receber votos, é que podemos pensar que a Justiça Eleitoral, ao cassar registro, diploma ou mandato eletivo, através dos processos judiciais que lhe são próprios, estará apenas cassando a vontade individual, privada e solitária de um cidadão candidato. E mais, que com isso, estará preservando e tutelando a vontade dos eleitores, a vontade das urnas, a soberania popular que, em verdade, foi a mais afetada, a realmente "cassada" com a decisão judicial ceifadora de registro, diploma ou mandato, notadamente quando se trata de candidato eleito.

Ao se impedir a realização da vontade das urnas, por cassação de registros, diplomas ou mandatos, se está, em verdade, cassando a vontade de todos os eleitores e do partido político ou coligação partidária que escolheram, juntos (partidos e eleitores), determinados candidatos. Escolha iniciada no processo que se deu com a admissão na grei partidária, passando pela escolha em convenção, pedido de registro, propaganda politica e aprovação final nas urnas.

Quando a cassação se dá sobre candidaturas proporcionais ${ }^{12}$, como são a de deputados fe-

12. Lei 9.504/97: "Art. 16-A. O candidato cujo registro esteja sub judice poderá efetuar todos os atos relativos à campanha eleitoral, inclusive utilizar o horário eleitoral gratuito no rádio e na televisão e ter seu nome mantido na urna eletrônica enquanto estiver sob essa condição, ficando a validade dos votos a ele atribuídos condicionada ao deferimento de seu registro por instância superior. (Incluído pela Lei no 12.034 , de 2009) Parágrafo único. O cômputo, para o respectivo partido ou coligação, dos votos atribuídos ao candidato cujo registro esteja sub judice no dia da eleição fica condicionado ao deferimento do registro do candidato. (Incluído pela Lei no 12.034, de 2009)"

Vale destacar o seguinte julgamento recente do TSE, em que o Ministro Marco Aurélio afirmou ser essa regra violante do princípio da Soberania Popular, sem, contudo, ter recebido o beneplácito, para esse entendimento, dos demais Ministros:

"Registro de candidato indeferido após as eleições e nulidade dos votos. O Plenário do Tribunal Superior Eleitoral, por maioria, reafirmou o entendimento de que os votos dados a candidato com registro indeferido após as eleições são nulos, nos termos do art.16-A, parágrafo único, da Lei no 9.504/1997. Vencido o Ministro Marco Aurélio, relator originário, que deferia a ordem, argumentando que, em razâo da soberania popular, os votos devem ser atribuidos à legenda no caso de indeferimento de registro ou de afastamento do candidato por outro motivo. Declarou, ainda, a inconstitucionalidade do parágrafo único do art. 16-A da Lei $n^{\circ}$ 9.504/1997, porque é conflitante com a Constituição da República. Nesse entendimento, o Tribunal, por 
derais, deputados estaduais e vereadores, a questão se complexifica em face das consequências sobre outros candidatos beneficiados pelos coeficientes partidário ${ }^{13}$ e eleitoral ${ }^{14}$, alcançados com o somatório de forças eletivas ${ }^{15}$.

Em síntese: ao se cassar registro de candidatura, diploma ou mandato eletivo de candidato eleito, ou seja, de candidato escolhido pelas urnas, está se cassando a soberania popular manifestada em cada unidade federada respectiva; está se cassando o exercício da soberania popular assentada na Constituição, através do exercício "tutelar" da vontade judicial, substitutiva da soberania popular, no caso. Isso é uma realidade vivida concretamente. Queiramos ou não, de fato, é isso que acontece, nos quadrantes da justiça eleitoral brasileira. E de 2000 até $2010^{16}$, foram mais de mil candidaturas eleitas, no Brasil, que sucumbiram ao crivo invalidatório judicial da vontade das urnas...

maioria, indeferiu a ordem. Mandado de Segurança no 4187-96/CE, redator para o acórdão Min. Dias Toffoli, em 7.8.2012"

Código Eleitoral: Art. 175. (...). $\$ 3^{\circ}$ Serão nulos, para todos os efeitos, os votos dados a candidatos inelegíveis ou não registrados. : (Parágrafo renumerado pelo art. 39 da Lei 4.961, de 45.66 ) $₫ 4^{\circ} \mathrm{O}$ disposto no parágrafo anterior não se aplica quando a decisão de inelegibilidade ou de cancelamento de registro for proferida após a realização da eleição a que concorreu o candidato alcançado pela sentença, caso em que os votos serão contados para o partido pelo qual tiver sido feito o seu registro. (Incluído pela Lei $n^{\circ} 7.179$, de 19.12.1983)

13. Código Eleitoral, artigo 107, define quociente partidário:"Determina-se para cada Partido ou coligação o quociente partidário, dividindo-se pelo quociente eleitoral o número de votos válidos dados sob a mesma legenda ou coligação de legendas, desprezada a fração. (Redação dada pela Lei no 7.454, de 30.12.1985)."

14. Código Eleitoral, artigo 106, define quociente eleitoral:"Determina-se o quociente eleitoral dividindo-se o número de votos válidos apurados pelo de lugares a preencher em cada circunscrição eleitoral, desprezada a fração se igual ou inferior a meio, equivalente a um, se superior."

15. Exemplo importante que não tem haver propriamente com a cassação do registro, mas seu indeferimento, é o seguinte: "Registro de candidatura. Eleição proporcional. Contagem. Voto, Legenda, Registro indeferido. Impossibilidade. Conforme jurisprudência consolidada do Tribunal Superior Eleitoral, não se computam, para a legenda, os votos dados ao candidato com o registro indeferido à data da eleição, ainda que a decisão no processo de registro só transite em julgado após o pleito. Os votos obtidos pelo candidato somente seriam computados para o partido a que é filiado se, no momento da eleição, estivesse ele com o registro deferido, ainda que posteriormente viesse a ser indeferido, conforme o disposto nos $\$ \S 3^{\circ}$ e $4^{\circ}$ do art. 175 do Código Eleitoral. O entendimento da Corte regional está em consonância com a orientação firmada neste Tribunal. Nesse entendimento, o Tribunal, por maioria, desproveu o agravo regimental. Agravo Regimental no Agravo de Instrumento no 11.326/RJ, rel. Min. Marcelo Ribeiro, TSE, em 1\%/2/2011."

O TSE confirmou essa posição em julgamento recente: "Recurso Especial Eleitoral no 54110-05/PI Relator originário: Ministro Marco Aurélio Redator para o acórdão: Ministro Dias Toffoli Ementa: RECURSO ESPECIAL. ELEIÇÕES 2008. RECURSO CONTRA EXPEDIÇÃO DE DIPLOMA. CANDIDATOS. REGISTROS INDEFERIDOS NA DATA DO PLEITO. CONTAGEM DOS VOTOS PARA A LEGENDA. IMPOSSIBILIDADE. RECURSO DESPROVIDO. 1. Os votos obtidos pelos candidatos com registro indeferido na data do pleito não poderão ser contados para a legenda pela qual concorreram, a teor do disposto nos $\$ \$ 3^{\circ}$ e $4^{\circ}$ do art. 175 do Código Eleitoral. 2. Recurso especial desprovido. DJE de 20.8.2012'.

16. Dado apresentado ao autor, pelo Ministro do TSE Henrique Neves, em seminário de ciência política e direito eleitoral, ocorrido em Teresina, Piauí, em junho de 2011. 
Foram mais de mil decisões de soberania popular, de unidades federadas, invalidadas por decisões autocráticas das autoridades judiciárias eleitorais.

E nas eleições municipais de 2012, esse número de invalidações tende a ser maior do que nas eleições municipais anteriores, não só por causa da lei ficha limpa e suas consequências nos processos de registro de candidaturas. Mas por que as candidaturas, partidos e coligações já contam, de certa forma, com a justiça eleitoral como sendo o rigue para o "segundo round" da luta política...

Diante dessa realidade insofismável, os efeitos da decisão contramajoritária da justiça eleitoral ao reconhecer hipóteses de delito eleitoral ou causas para tanto ${ }^{17}$, quando se trata de candidato eleito, são sempre erga omnes, nunca inter partes. Essa decisão tem efeito geral impactante sobre a real vontade das urnas, a soberania popular, vontade livre e democrática dos eleitores, candidatos e partidos políticos.

\section{V}

Não existem trabalhos entre nós que problematizem essas decisões judiciais como decisões contramajoritárias. Como decisões que judicializaram, ao extremo, questóes políticas fundamentais da comunidade, do corpo político, do colégio eleitoral. Como decisóes judiciais autocráticas que invalidam a vontade popular majoritária.

Ou ainda: não há estudos que enquadrem, o nosso Judiciário Eleitoral, como poder constituído que está a exercer, em termos graves, a sua função contramajoritária. A função de contrariar a vontade popular das urnas, invalidando-a, tornando-a "nenhum", podando-lhe os efeitos "instituintes" de mandatos! A sua função sobrepujadora, em verdade, da própria soberania popular.

No âmbito da doutrina constitucional ${ }^{18}$, quando se fala no controle de constitucionalida-

17. Isso quando se dá tal efeito próprio às decisões tomadas em ações de investigação judicial eleitoral que tematizem abuso de poder político, econômico ou dos meios de comunicação social; ação por capitação ilícita de sufrágio, pela incidência do 41-A, da lei 9.9840.99; representação por conduta vedada; recurso contra expedição de diploma; ação de perda de mandato eletivo; ação de impugnação de registro de candidatura; ação de repressão a gastos e arrecadações eleitorais ilícitas, etc.

18. Ver importante livro do professor argentino GARGARELLA, Roberto, La Justicia Frente al Gobierno. Sobre el Carácter Contramayoritario del Poder Judicial. Apres. Cass Sunstein. Barcelona: Ariel, 1996. 279 p.

No Brasil, no largo espectro do tema: BINENBOJM, Gustavo. A Nova Jurisdição Constitucional Brasileira: legitimidade democrática e instrumentos de realização. Rio de Janeiro: Renovar, 2001.260 p; ROCHA JÚNIOR, José Jardim. "Problemas com o governo dos juízes sobre a legitimidade democrática do judicial review”. Revista de Informação legislativa, ${ }^{a}$ 38, jul/set 2001, p. 255-78; ) SOUZA NETO, Cláudio Pereira. Jurisdição Constitucional, Democracia e Racionalidade Prática. Rio de Janeiro: Renovar, 2002. 378 p; STAMATO, Bianca. Jurisdição Constitucional. Rio de Janeiro: Lumem Juris, 2005. 272 p.; MORO, Sergio Fernando. Jurisdição Constitucional como Democracia. São Paulo: Revista dos Tribunais, 2004. 335 p. MENDES, Conrado Hübner. Direitos Fundamentais, Separação de Poderes e Deliberação. São Paulo: Saraiva, 2011. 254 p. BARROSO, Luis Roberto, no post-scriptum “Constituição, Democracia e Supremacia Judicial: Direito e Política do Brasil Contemporâneo", p. 357-404, de seu livro O Controle de Constitucionalidade no Direito Brasileiro, 5 ed., São Paulo, Saraiva, 2011, 446 p.

Ver ainda o destacado autor norte-americano WALDRON, Jeremy, em seu artigo traduzido para nossa língua "A Essência da Oposição ao Judicial Review", publicado em obra coletiva organizada por Antonio Car- 
de como instrumento contramajoritário de anulação da vontade dos representantes feitores de leis, se diz que o Judiciário, ao assim proceder, exerce poder contramajoritário, eis que uma minoria de homens (os juízes), sem investidura eletiva popular, invalida o trabalho coletivo de muitos, que o fizeram em nome de seus representados, os cidadãos que os elegeram.

O tema crítico da idéia de poder contramajoritário questiona a própria legitimidade da justiça constitucional em anular a vontade de uma maioria parlamentar por uma minoria não eletiva ${ }^{19}$ : a minoria encontrável no Judiciário, em nossa realidade, juízes de comarca ou juízes de tribunal. Na justiça eleitoral: juizes de zona eleitoral e tribunais plenários.

Ou seja, questiona-se a conveniência, oportunidade e legitimidade de uma minoria não eleita pelos cidadãos anular o trabalho de uma maioria parlamentar livre e democraticamente escolhida nas urnas; questiona-se o valor desta anulação da vontade popular presente nas leis, por uma aristocracia judiciária sem respaldo em eleição direta ${ }^{20}$; questiona-se pelo fato dos cidadãos eleitores esperarem que as suas vontades, agora leis, elaboradas pelos seus representantes políticos legítimos, sejam cumpridas e não tornadas sem efeito por quem não recebeu a chancela do colegiado eleitoral.

Esse questionamento crítico também demonstra argumentos que são favoráveis aos juízes e suas competências de invalidação de leis inconstitucionais, pois ao fazerem assim protegem a vontade constituinte, a Constituição, e ao anularem leis, estão entendendo que as mesmas são inválidas por que desconformes a parâmetros formais ou materiais, a regras ou princípios assentes numa Constituição, numa vontade superior e antecedente à vontade popular manifestada nas leis: a vontade de constituição.

Assim, no controle de constitucionalidade, julga-se um produto mediato da vontade dos representados, cidadãos eleitores: julga-se a lei, produto da vontade dos representantes eleitos (candidatos investidos de mandato, portanto empossados), que, eventualmente, pode, como vontade popular indireta, estar em franco desacordo com a suprema vontade constituinte, vontade inaugural, representada pela Constituição.

\footnotetext{
los Alpino Bigonha e Luiz Moreira, Legitimidade da Jurisdição Constitucional,. E ainda, deste mesmo autor, "O Judicial Review e as Condições da Democracia”, em outra obra coletiva organizada por Antonio Carlos Alpino Bigonha e Luiz Moreira, Limites do Controle de Constitucionalidade, Rio de Janeiro, Lumem Juris, 2009 , p. 243-270.

19. Roberto Gargarella, em seu livro La Justicia Frente al Gobierno. Sobre el Carácter Contramayoritario del Poder Judicial, ob. cit., p. 11, questiona: a) Como pode ser que em uma democracia, os juízes tenham a possibilidade de anular uma lei aprovada pelos representantes da maioria do povo? b) Como pode ser que um minúsculo grupo de juízes, que não são eleitos diretamente pela cidadania (como são a maioria dos agentes públicos), e que não estão sujeitos a eleições populares periódicas (já que tem vitaliciedade, e estão livre, assim, de escolhas por votaçóes públicas), possam prevalecer, em última instância, sobre a vontade popular?

20. Luis Roberto Barroso, sem seu livro O Controle de Constitucionalidade no Direito Brasileiro, ob. cit., com citação do jurista norte-americano Alexander Bickel, nos esclarece sobre o termo "dificuldade contramajoritária”, ao tratar sobre a crítica à expansão da intervenção judicial na vida brasileira. Barroso retira da obra The Least Dangerous Branch, a seguinte passagem: "A questão mais profunda é que o controle de constitucionalidade (judicial review) é uma força contramajoritária em nosso sistema (...) Quando a Suprema Corte declara inconstitucional um ato legislativo ou um ato de um membro eleito do Executivo, ela se opóe à vontade de representantes do povo, o povo que está aqui e agora; ela exerce um controle, não em nome da maioria dominante, mas contra ela (...). O controle de constitucionalidade, no entanto, é o poder de aplicar e interpretar a Constituição, em matéria de grande relevância, contra a vontade da maioria legislativa, que, por sua vez, é importante para se opor à decisão judicial." (p. 367).
} 
Nessa doutrina crítica, referem seus divulgadores ${ }^{21}$, que os juízes, quando lidam com o controle de constitucionalidade, devem se autoconterem, se autocontrolarem, para que não substituam a vontade do legislador, dos representantes do povo, pelas suas próprias vontades.

Nesse sentido acusa-se o controle de constitucionalidade - o expediente jurídico de invalidação de leis, de produtos das vontades diretas dos representantes e indiretas dos representados - de ocasionar um impasse, entre constitucionalismo e democracia, pois em certos momentos da vida institucional ocorrem entrechoques entre a vontade judicial e a vontade majoritária parlamentar. A vontade judicial querendo fazer prevalecer a separação de poderes e direitos fundamentais, bases do constitucionalismo, em face de decisóes populares ou congressuais que lhe são contrárias - expressões da democracia representativa -, segundo a interpretação última dada pelo Judiciário em sua função contramajoritária.

\section{VI}

Ora, se são relevantes e pertinentes tais considerações para o controle de constitucionalidade que invalida leis - invalidação que afeta a vontade mediata do povo exercida através de seus representantes eleitos -, mas intrigantes e apropriadas ficam tais questóes "contramajoritárias" se focarmo-nos no que nossa justiça eleitoral tem feito com a vontade imediata do povo, com o produto imediato da vontade das urnas: a escolha dos candidatos, dos representantes mesmos do povo - escolhas que são invalidadas em pleitos judiciais eleitorais; escolhas nulificadas, tornadas sem efeito, como reflexos de cassaçóes de registros ${ }^{22}$,

21. Ver importante artigo do constitucionalista e Desembargador Federal do TRF1, Néviton Guedes, intitulado "O juiz entre o ativismo judicial e a autocontenção", publicado na Revista Consultor Jurídico, de 23 de julho de 2012. Referindo-se às ideias de Oliver Wendell Holmes, afirmou que “(....) a prática do Direito só poderia ser bem exercida com boa dose de autocontenção por parte dos juízes. (...)." E citando John Marshall, nos ensina que "os tribunais são meros instrumentos da lei" e, na sua atividade, não podem ter vontade própria: "O Poder Judiciário nunca pode ser exercido com o propósito de dar efetividade à vontade do magistrado; (mas) sempre com a finalidade de realizar a vontade da legislatura, ou, em outras palavras, a vontade da lei". E adiante, retratou: "numa democracia, havendo espaço de discricionariedade conferida pela Constituição, são a vontade e a escolha do legislador que - legitimamente exercida - devem prevalecer. Ainda que outras possibilidade de decisão fossem reconhecidas,. (....) as Constituições elegem o Poder Legislativo, não o Judiciário, como o concretizador privilegiado da Constituição. Suas decisões, portanto, não podem ser - sem mais - desconsideradas por órgãos do Poder Judiciário." (p. 02)

22. Algumas hipóteses de cassação de registro previstas na ordem jurídica: na Lei 9.504/97: Art. 41-A. Ressalvado o disposto no art. 26 e seus incisos, constitui captação de sufrágio, vedada por esta Lei, o candidato doar, oferecer, prometer, ou entregar, ao eleitor, com o fim de obter-lhe o voto, bem ou vantagem pessoal de qualquer natureza, inclusive emprego ou função pública, desde o registro da candidatura até o dia da eleição, inclusive, sob pena de multa de mil a cinqüenta mil Ufir, e cassação do registro ou do diploma, observado o procedimento previsto no art. 22 da Lei Complementar no 64, de 18 de maio de 1990.(Incluído pela Lei nº 9.840, de 28.9.1999)"'“Art. 73. São proibidas aos agentes públicos, servidores ou não, as seguintes condutas tendentes a afetar a igualdade de oportunidades entre candidatos nos pleitos eleitorais: I - ceder ou usar, em benefício de candidato, partido político ou coligação, bens móveis ou imóveis pertencentes à administração direta ou indireta da União, dos Estados, do Distrito Federal, dos Territórios e dos Municípios, ressalvada a realização de convenção partidária; II - usar materiais ou serviços, custeados pelos Governos ou Casas Legislativas, que excedam as prerrogativas consignadas nos regimentos e normas dos órgãos que integram; III - ceder servidor público ou empregado da administração direta ou indireta federal, estadual ou municipal do Poder Executivo, ou usar de seus serviços, para comitês de campanha eleitoral de candidato, partido político ou coligação, durante 


\section{diplomas $^{23}$ ou mandatos ${ }^{24}$ eletivos.}

o horário de expediente normal, salvo se o servidor ou empregado estiver licenciado; IV - fazer ou permitir uso promocional em favor de candidato, partido político ou coligação, de distribuição gratuita de bens e serviços de caráter social custeados ou subvencionados pelo Poder Público; V - nomear, contratar ou de qualquer forma admitir, demitir sem justa causa, suprimir ou readaptar vantagens ou por outros meios dificultar ou impedir o exercício funcional e, ainda, ex officio, remover, transferir ou exonerar servidor público, na circunscrição do pleito, nos três meses que o antecedem e até a posse dos eleitos, sob pena de nulidade de pleno direito, ressalvados: a) a nomeação ou exoneração de cargos em comissão e designação ou dispensa de funçóes de confiança; b) a nomeação para cargos do Poder Judiciário, do Ministério Público, dos Tribunais ou Conselhos de Contas e dos órgãos da Presidência da República; c) a nomeação dos aprovados em concursos públicos homologados até o início daquele prazo; d) a nomeação ou contratação necessária à instalação ou ao funcionamento inadiável de serviços públicos essenciais, com prévia e expressa autorização do Chefe do Poder Executivo; e) a transferência ou remoção ex officio de militares, policiais civis e de agentes penitenciários; VI - nos três meses que antecedem o pleito: a) realizar transferência voluntária de recursos da União aos Estados e Municípios, e dos Estados aos Municípios, sob pena de nulidade de pleno direito, ressalvados os recursos destinados a cumprir obrigação formal preexistente para execução de obra ou serviço em andamento e com cronograma prefixado, e os destinados a atender situações de emergência e de calamidade pública; b) com exceção da propaganda de produtos e serviços que tenham concorrência no mercado, autorizar publicidade institucional dos atos, programas, obras, serviços e campanhas dos órgãos públicos federais, estaduais ou municipais, ou das respectivas entidades da administração indireta, salvo em caso de grave e urgente necessidade pública, assim reconhecida pela Justiça Eleitoral; c) fazer pronunciamento em cadeia de rádio e televisão, fora do horário eleitoral gratuito, salvo quando, a critério da Justiça Eleitoral, tratar-se de matéria urgente, relevante e característica das funções de governo; VII - realizar, em ano de eleição, antes do prazo fixado no inciso anterior, despesas com publicidade dos órgãos públicos federais, estaduais ou municipais, ou das respectivas entidades da administração indireta, que excedam a média dos gastos nos três últimos anos que antecedem o pleito ou do último ano imediatamente anterior à eleição. VIII - fazer, na circunscrição do pleito, revisão geral da remuneração dos servidores públicos que exceda a recomposição da perda de seu poder aquisitivo ao longo do ano da eleição, a partir do início do prazo estabelecido no art. $7^{\circ}$ desta Lei e até a posse dos eleitos. (....) $₫ 50$ Nos casos de descumprimento do disposto nos incisos do caput e no $\S 10$, sem prejuízo do disposto no $\S 4 \mathrm{o}$, o candidato beneficiado, agente público ou não, ficará sujeito à cassação do registro ou do diploma. (Redação dada pela Lei no 12.034 , de 2009) Art. 74. Configura abuso de autoridade, para os fins do disposto no art. 22 da Lei Complementar $n^{\circ} 64$, de 18 de maio de 1990, a infringência do disposto no $₫ 1^{\circ}$ do art. 37 da Constituição Federal, ficando o responsável, se candidato, sujeito ao cancelamento do registro ou do diploma. (Redação dada pela Lei no 12.034, de 2009) Art. 75. Nos três meses que antecederem as eleições, na realização de inaugurações é vedada a contratação de shows artísticos pagos com recursos públicos. Parágrafo único. Nos casos de descumprimento do disposto neste artigo, sem prejuízo da suspensão imediata da conduta, o candidato beneficiado, agente público ou não, ficará sujeito à cassação do registro ou do diploma. (Incluído pela Lei no 12.034, de 2009)"

23. Algumas hipóteses de cassação de diploma previstas na ordem jurídica: além das referidas na nota anterior, as clássicas hipóteses referidas do artigo Art. 262 do Código Eleitoral: "O recurso contra expedição de diploma caberá somente nos seguintes casos: I - inelegibilidade ou incompatibilidade de candidato; II errônea interpretação da lei quanto à aplicação do sistema de representação proporcional; III - erro de direito ou de fato na apuração final, quanto à determinação do quociente eleitoral ou partidário, contagem de votos e classificação de candidato, ou a sua contemplação sob determinada legenda; IV - concessão ou denegação do diploma em manifesta contradição com a prova dos autos, nas hipóteses do art. 222 desta Lei, e do art. 41-A da Lei no 9.504, de 30 de setembro de 1997. (Redação dada pela Lei n 9.840, de 28.9.1999)"

24. Algumas hipóteses de cassação de mandato (por questóes eleitorais) previstas na ordem jurídica: na Constituição da República:"Art. 14. A soberania popular será exercida pelo sufrágio universal e pelo voto direto e secreto, com valor igual para todos, e, nos termos da lei, mediante: (...) $₫ 10$ - O mandato eletivo poderá ser impugnado ante a Justiça Eleitoral no prazo de quinze dias contados da diplomação, instruída a ação com provas de abuso do poder econômico, corrupção ou fraude." Algumas hipóteses de cassação de mandato (por questóes eleitorais) previstas na ordem jurídica: na Constituição da República:"Art. 14. A soberania popular será exercida pelo sufrágio universal e pelo voto direto e secreto, com valor igual para todos, e, nos termos da lei, mediante: (...) $\S 10$ - O mandato eletivo poderá ser impugnado ante a Justiça Eleitoral no prazo de quinze dias contados da diplomação, instruída a ação com provas de abuso do poder econômico, corrupção ou fraude." 
Vale ouvir, para o ponto, as lúcidas reflexões de Néviton de Oliveira Batista Guedes:

"As atuais eleições municipais [2012] serão sem dúvida aquelas em que a Justiça Eleitoral demonstrará o maior poder de intervenção no processo de escolha dos representantes do povo. Como sabem todos aqueles que lidam com o Direito Eleitoral em nosso país, a legislação hoje em vigor permite ao Judiciário uma ingerência no processo eleitoral absolutamente inédita em qualquer lugar do planeta.

Estudiosos do Direito Eleitoral, mesmo saudando, em unânime manifestação, o espetacular papel que a Justiça Eleitoral tem cumprido em nosso país desde que foi criada, vêm agora observando com honesta e sentida reserva o inadequado incremento das competências do Poder Judiciário no sistema eleitoral brasileiro.

A Justiça Eleitoral hoje, não se limitando à certificação dos poderes dos candidatos vitoriosos, como sabemos todos, pode intervir e acaba intervindo no conteúdo e no próprio resultado do processo eleitoral. O magistrado eleitoral brasileiro, graças a uma jurisprudência e legislação cada vez mais ambiciosas, tem o poder não apenas de certificar os registros de candidaturas e proclamar e diplomar os eleitos, mas também de cassar mandatos alcançados com o voto popular, tornar inelegíveis os cidadãos e, inclusive, sindicar e censurar o que os candidatos podem dizer e os eleitores podem ouvir numa campanha eleitoral. Boa parte dessas funçôes, como é o caso do registro de candidatura, podem ser exercidas de ofício e incidem diretamente sobre alguns dos mais caros direitos fundamentais dos cidadãos. Aliás, nunca é demasiado lembrar: a capacidade de votar e a de ser candidato correspondem a direitos fundamentais dos mais prestigiados em todo mundo civilizado e democrático, não obstante sem muita cerimônia sofram, no Brasil, restriçóes impostas até mesmo por meros atos normativos secundários (Resoluções) da Justiça Eleitoral.

O juiz eleitoral acaba, inclusive, tendo influência mesmo do ponto de vista político sobre as eleiçóes. Com efeito, como sabemos todos, basta a rejeição judicial, mesmo que provisória, de um registro de candidatura, ou apenas a censura a algumas veiculaçóes de propaganda eleitoral, para que o candidato, ainda que alcance reformar definitivamente a decisão em instâncias superiores, acabe politicamente perdendo as eleiçóes, já que o eleitor invariavelmente empresta acentuada importância às manifestaçóes do Poder Judiciário.

Isso já seria o bastante para advertir o magistrado da extrema cautela como deve se mover com os poderes que lhe são conferidos em matéria eleitoral. Quando imaginamos que a democracia, como diz a Constituição, é um regime em que o poder emana do provo e em seu nome é exercido, fazendo-o diretamente ou por seus representantes eleitos, qualquer intervenção de qualquer órgão, seja da sociedade civil ou do Estado, no processo eleitoral, antes de tudo tem que ser observada com extremada prudência e muita reserva.

O Poder Judiciário, os promotores eleitorais, os advogados eleitorais, só podem pretender interferir na relação direta que deve existir entre o eleitor e o candidato quando 
isso se fizer realmente necessário. Com uma legislação tão interventiva como é a legislação que hoje disciplina as eleições, o que é reconhecido tanto por aqueles que a criticam como aqueles que a aplaudem, o medo é que assalte em todos nós, que atuamos com o direito, uma tentação de intervenção demasiada, para além, inclusive, do que já se manifesta na própria lei, de tal maneira que, ao invés de colaboramos para o processo de formação de vontade livre do povo, pois é disso que se cuida a democracia, acabemos por comprometer essa mesma liberdade do eleitor, que é quem, afinal de contas, numa democracia, deve ter a última palavra." ${ }^{25}$

Assim, como podemos ver, em nosso contexto judiciário se agiganta a problemática "contramajoritária" ao anularem os juízes eleitorais registros de candidatura pós-eleições, ou cassarem diplomas conferidos aos eleitos ou mandatos exercidos pelos candidatos diplomados e empossados.

Destarte, precisamos, no Brasil, em termos reflexivos, aproveitarmos desses questionamentos críticos do self restring, no controle de constitucionalidade, para traçarmos uma doutrina de autocontrole do judiciário eleitoral no delicado e complexo processo de invalidação de vontade direta das urnas, para escolha de candidatos.

Isso não só em homenagem e por necessidade do princípio constitucional da soberania popular (concretizador dos princípios estruturantes da Democracia e República). Mas também por respeito ao devido processo legal eleitoral, que deve reger, com justiça, decisões judiciais que incidirão sobre os direitos políticos fundamentais de votar e ser votado; liberdades-participação que sofrerão controle ou cerceamento legítimo na medida em que as leis materiais e leis processuais sejam produzidas legislativamente e interpretadas judicialmente de acordo com os elevados fins republicanos do Estado Democrático de Direito, fins tuteláveis pela justiça eleitoral.

E as liberdades políticas de votar, de receber votos, de escolha por partidos de candidaturas, são bens jurídicos, direitos fundamentais concretizantes dos princípios constitucionais da República e da Soberania Popular. E o devido processo legal em sua dupla dimensão, a material - vinculando o legislador eleitoral -, e a formal - vinculante do juiz eleitoral e do administrador lidante, direta ou indiretamente, com temas eleitorais -, deve ser conformado de tal modo que produza na melhor medida possível efetividade protetiva para tais direitos fundamentais, chamados de liberdades políticas de participação, liberdades-participação (Celso de Mello).

Ou seja: é preciso construirmos doutrina que demonstre que o Judiciário Eleitoral, ao exercer função contramajoritária em face de escolhas políticas das urnas, deve fazê-lo aplicando leis justas e proporcionais, mediante procedimentos judiciais e hermenêuticos que prestigiem a idéia de um justo processo eleitoral, que preserve a soberania popular em sua inteireza, como vontade dos eleitores, dos candidatos e dos partidos políticos, sem inclinar a balança, desproporcionalmente para qualquer desses titulares de liberdades políticas, ou pior, contra todos, ao argumento retórico e fictício de anular a vontade popular para protegê-la...

Nessa perspectiva, não podemos aceitar que se produzam leis eleitorais açodadas, justiceiras e irracionais, despidas de boa técnica jurídica e constitucionalidade, como a lei ficha

25. Em seu As eleições municipais e o processo de democracia, Revista Consultor Jurídico, 17 de setembro de 2012, coluna "Constituição e Poder". 
limpa ${ }^{26}$. Não podemos admitir que o apelo plebiscitário e midiático "das ruas" substitua, com sua passionalidade e moralidade, as exigências de racionalidade e constitucionalidade impostas pela Constituição a todos os poderes sociais e estatais da República.

Nesse horizonte crítico, igualmente, não podemos aceitar que o Judiciário eleitoral "crie" normas jurisprudenciais ou tribunalícias ou adote posturas hermenêuticas que façam fenecer no plano da práxis judicial os direitos políticos fundamentais de votar e ser votado.

Para dar concretude a nossa crítica, exemplificamos casos ocorridos no TSE: a "norma jurisprudencial" ${ }^{27}$, antes da emergência da lei ficha limpa, que prescrevia que aquele que deu causa a anulação da eleição, ex vi do decantado princípio da proporcionalidade, não poderia participar da eleição suplementar, criando-se, com tal exegese contra constitutione, inelegibilidade por jurisprudência, e não por lei complementar; a regra de resolução, que contra dispositivo expresso de lei eleitoral, "criou" transversa hipótese de inelegibilidade por norma "regulamentar"28, ao entender que aqueles que tiveram as contas desaprovadas, não poderiam obter certidão eleitoral, assim, não poderiam obter registro de candidatura ${ }^{29}$; a postura antes de pré-compreensão do que de interpretação, que afirma que inelegibilidade não seria pena ${ }^{30}$,

26. Indicamos, sobre a (i)constitucionalidade da lei ficha limpa, nossos artigos sobre o assunto, em termos crítico-reflexivos: ESPÍNDOLA, Ruy Samuel. A Lei Ficha Limpa em revista e os empates no STF. O dilema entre o politicamente correto e o constitucionalmente sustentável. Jus Navigandi, Teresina, ano 15, n. 2711, 3 dez. 2010. Disponível em: < http://jus.uol.com.br/revista/texto/17925>. Acesso em: 1 maio 2011; Lei Ficha Limpa estadual e suas inconstitucionalidades. O caso de Santa Catarina. Jus Navigandi, Teresina, ano 16, n. 3035, 23 out. 2011. Disponível em: <http://jus.com.br/revista/texto/20180>. Acesso em: 23 out. 2011. STF, insegurança jurídica e eleiçóes em 2012: Até quando o embate entre moralistas e constitucionalistas em torno da lei ficha limpa? Jus Navigandi, Teresina, ano 16, n. 2827, 29 mar. 2011. Disponível em: <http://jus.uol.com.br/revista/texto/18790>. Acesso em: 2 maio 2011.

27. "[...] Registro de candidatura. Pleito. Renovação. Candidato que deu causa à anulação. Participação. Impossibilidade. Processo. Art. 15 da Lei Complementar no 64/90. Não-incidência. [...] 1. O art. 15 da Lei Complementar $n^{\circ} 64 / 90$, nos processos de registro de candidatura, aplica-se apenas às hipóteses em que se discute inelegibilidade. [...]” (Ac. de 2.8.2007 no AgRgREspe n 28.116, rel. Min. Caputo Bastos.)

28. Ver nossa crítica sobre o tema em artigo: ESPÍNDOLA, Ruy Samuel. Abuso do Poder Regulamentar e TSE: contas eleitorais rejeitadas e quitação eleitoral - as eleições de 2012 (reflexos do "moralismo eleitoral"). Revista Brasileira de Direito Eleitoral. RBDE. Belo Horizonte: Fórum, ano 4, n. 6, jan/jun, 2012.

29. O que em termos pragmáticos, dentro de um conceito juridicamente adequado de inelegibilidade, é o mesmo que incidir em inelegibilidade, conforme Adriano da Costa Soares.

30. Já fizemos crítica a esse entendimento, em artigo de nossa autoria: ESPÍNDOLA, Ruy Samuel. Lei Ficha Limpa estadual e limites constitucionais de sua produção legislativa. Análise da inacessibilidade a cargos em comissão por condenados por improbidade administrativa sem trânsito em julgadoł o caso da lei catarinense. Revista Brasileira de Direito Eleitoral. RBDE. Belo Horizonte: Fórum, ano 3, n. 5, jul./ dez, 2011. Vejamos parte de nossos argumentos críticos:

"Não é possível se "importar" o inaceitável equívoco propalado pelos apologistas da lei ficha limpa eleitoral, ao dizerem que “inelegibilidade não é pena”. Afirmar se inelegibilidade é ou não pena é papel da Ciência Jurídica, da Teoria do Direito. O Direito Penal, o Direito Administrativo e o Direito Eleitoral se beneficiam de seus aportes explicativos e conceituais.

A Teoria do Direito, (HANS KELSEN, Teoria Geral do Direito e do Estado, São Paulo, Martins Fontes, 1990, P. 53/61. NOBERTO BOBBIO, Teoria da Norma Jurídica, trad. Fernando Pavan e Ariani Bueno. 2 ed. São Paulo, Edipro, 2003, p. 145/176.) afirma que sanção (pena) é toda conseqüência limitadora de um direito, de uma liberdade, de um patrimônio moral ou material, decorrente de comportamento juridicizado como ilícito por norma de direito. Comportamento que resulta, para a pessoa que o realiza, a incidência de 
mas mero requisito para o pedido de candidatura, portanto, pode retroagir a lei que dela trate, ainda que em prejuízo do direito político fundamental de ser votado, com exegese não só contrária a esse direito, mas à hermenêutica constitucional, no que toca ao princípio da máxima efetividade dos direitos fundamentais.

Isso para que o Judiciário eleitoral não se transforme em eleitor privilegiado ou eleitor negativo (para parafrasear a idéia de legislador negativo de Kelsen), com atuação própria de "Juízes filósofos", ao modo elitista pensado por Platão, em sua Política, ao falar dos "reis filósofos". $\mathrm{Ou}$ seja, Juízes platônicos que dirão, no lugar dos eleitores, quem deverá representá-los ou dirão, de maneira negativa, quem não deverá representá-los. Assim, é preciso alta reflexão e adequada contenção legal e hermenêutica, para que o Judiciário eleitoral não substitua a vontade dos eleitores, dos partidos políticos e dos candidatos, não substitua a vontade popular pela sua vontade - a vontade judicial não eleita, mas indevidamente eletiva, quando posta em lugar da vontade das urnas.

No sentido ora criticado, o Judiciário, repita-se, seria eleitor negativo por que impediria efeitos à eleição já consolidada nas urnas; impediria a posse ou exercício de candidato cujo registro, diploma ou mandato, fora cassado em regular processo judicial eleitoral.

Por outro lado, em nosso sistema jurídico-eleitoral há também a hipótese do Judiciário eleitoral ser eleitor positivo, de franca substituição da vontade popular das urnas pela vontade dos juízes eleitorais, nos casos em que, anulada uma eleição, o segundo colocado para o Executivo é que será diplomado e empossado no lugar do primeiro lugar, conforme o escore das urnas. ${ }^{31}$

Também isso acontece em eleição majoritária para o Senado. Ou em eleições proporcionais, onde assumirá o suplente do partido ou coligação, ou haverá inversão do coeficiente partidário, com diplomação e posse de candidatos adversários de partidos vencedores nas urnas, mas perdedores no Judiciário eleitoral.

Além dessas duas hipóteses, funcionar o Judiciário eleitoral como eleitor negativo ou eleitor positivo, no lugar do corpo de eleitores, pode haver decisóes judiciais que subtraiam da soberania popular, do escrutínio popular, a escolha direta de candidatos. Decisões que coloquem em xeque a idéia de voto direto, periódico e universal. Ou seja, o Judiciário não atuaria como eleitor, mas sensor máximo não só do eleitorado, mas da própria soberania popular representativa.

certa carga restritiva ou ablativa de liberdade em sua esfera jurídica. A sanção é o consequente do descumprimento da norma: acarreta pena a quem prática o comportamento vedado pelo direito.

Ora, estaremos sim diante de sanção, medida punitiva, ablativa de direitos, sempre que um ato humano puder ser valorado como ilícito e justificante de uma limitação da liberdade. Tudo baseado em norma de direito, que limita um comportamento, estabelece consequências de sua prática e define uma autoridade para julgá-lo."

31. É o caso típico em eleições municipais, em que há mais de duas chapas, e a que vence as eleições não tem $50 \%$ + um voto. Nessa hipótese se dá diploma e posse aos segundos colocados: e.g. Acórdão de 17/08/2006 - Rel. Min. JOSÉ AUGUSTO DELGADO - DJ 01/11/2006: RECURSO ESPECIAL. CASSAÇÃO DE DIPLOMA. ART. 41-A DA LEI No 9.504/97. ELEIÇÕES MUNICIPAIS. PREFEITO E VICE-PREFEITO. QUEBRA DE SIGILO BANCÁRIO. POSSIBILIDADE. PRECEDENTE DO STF. ANULAÇÃO DOS VOTOS VÁLIDOS. NÃO-INCLUSÃO DOS VOTOS NULOS. REEXAME DE PROVAS. NEGADO PROVIMENTO.(...). 5. Anulados menos de $50 \%$ dos votos válidos, impõe-se a posse do candidato segundo colocado, e não a aplicação do comando posto no art. 224 do Código Eleitoral. (...)." 
São decisóes judiciais que retiram do voto a sua cláusula constitucional de imediatidade entre eleitor e eleito. Trata-se da questionável jurisprudência do TSE ${ }^{32}$, para a qual nos cargos de Chefia do Poder Executivo, se a vacância de governadorias ou prefeituras, por questóes ligadas a processos eleitorais, se der nos dois últimos anos de mandato, a escolha não será mais por eleição direta das urnas, mas por eleição indireta pelas casas parlamentares. Eleições em que só podem votar os parlamentares e só podem se candidatar eles mesmos.

Ou seja, a liberdade de votar e de receber votos foi subtraída dos cidadãos eleitores ou cidadãos candidatos, e colocada, em termos aristocráticos, ao exercício privilegiado e diminuto de uma assembléia parlamentar que as exercerá diretamente; fará tudo entre os próprios pares, sem acesso de qualquer outro cidadão que não o parlamentar em exercício de mandato no momento da eleição parlamentar indireta.

A tal hermenêutica se chegou pelo uso imperfeito da hipótese referida no artigo $81, \S$ $1^{\circ}$, da $\mathrm{CF}^{33}$, que trata da sucessão no Executivo, por causas constitucionais e não por causas eleitorais. $^{34}$

32."Cassação. Primeiro biênio. Prefeito e vice-prefeito. Convocação. Eleições diretas. Princípio da simetria. A jurisprudência do Tribunal Superior Eleitoral tem firmado a orientação de que o disposto no $\S 1^{\circ}$ do art. 81 da Constituição Federal deve ser observado pelos entes federados, em razão do princípio da simetria, devendo ser realizada eleição indireta caso a vacância ocorra nos dois últimos anos do mandato, independentemente de ser causa eleitoral ou não. Assim, é lícita a convocação de eleições diretas, para fevereiro de 2011, para a complementação do mandato de prefeito e vice-prefeito, eleitos em 2008 e cassados em sede de ação de impugnação de mandato eletivo, uma vez que a vacância dos cargos ocorreu ainda no primeiro biênio do mandato.

Nesse entendimento, o Tribunal, por unanimidade, negou seguimento ao mandado de segurança. Mandado de Segurança no 186-34/RJ, rel. Min. Marcelo Ribeiro, em 3/2/2011."

E o TSE confirmou essa posição em julgamento de 23.08.12:

"Dupla vacância e eleição indireta. O Plenário do Tribunal Superior Eleitoral reafirmou o entendimento de que, na hipótese de dupla vacância dos cargos de prefeito e vice-prefeito e estando em curso o último ano do mandato, a eleição deve ser realizada na modalidade indireta. Asseverou que a assunção da chefia do Poder Executivo, em caráter definitivo, pelo presidente da Câmara Municipal em razão de dupla vacância dos cargos de prefeito e vice-prefeito, a despeito da previsão na Lei Orgânica do Município, não se coaduna com o regime democrático e com a soberania popular. Pontuou que, na hipótese dos autos, a realização de eleições diretas a menos de dois meses das Eleições 2012 acarretaria a movimentação da estrutura da Justiça Eleitoral - já comprometida com a organização do pleito vindouro - e o dispêndio de elevados valores monetários a fim de se eleger novo prefeito para o desempenho de brevíssimo mandato. A Ministra Cármen Lúcia acompanhou a relatora em razão da proximidade das eleições, mas ressalvou que é favorável às eleições diretas.

Nesse entendimento, o Tribunal, por unanimidade, concedeu a ordem. Mandado de Segurança no 34625/PI, rel. Min. Nancy Andrighi, em 23.8.2012."

33. "Art. 81. Vagando os cargos de Presidente e Vice-Presidente da República, far-se-á eleição noventa dias depois de aberta a última vaga. $\S 1^{\circ}$ - Ocorrendo a vacância nos últimos dois anos do periodo presidencial, a eleição para ambos os cargos será feita trinta dias depois da última vaga, pelo Congresso Nacional, na forma da lei. $\$ 2^{\circ}$ - Em qualquer dos casos, os eleitos deverão completar o período de seus antecessores".

34. Em trabalho forense de 11 de junho de 2003 (mandado de segurança em matéria eleitoral), discutimos essa distinção entre causas constitucionais e causas eleitorais. Valendo relembrá-lo, trazendo breve excerto, para fins deste ensaio: 
"18. A Autoridade Impetrada, com seu procedimento ilegal, trata o problema em foco como extinção de mandato, como problema de sua competência parlamentar, e não como deveria sê-lo, cassação de diploma, cuja competência é deste Juízo, da Justiça Eleitoral. Ela objetiva frustrar a jurisdição saneadora do Colendo Tribunal Superior Eleitoral e coarctar os direitos subjetivos públicos dos Impetrantes.

Impetrantes que, segundo as regras do devido processo eleitoral, sãos os legitimos expectantes a serem diplomados, para, ao depois, tomarem posse nos cargos respectivos de Prefeito e Vice-Prefeito, segundo as regras jurídicas pertinentes à legislação eleitoral e a mais recente e autorizada jurisprudência eleitoral do TSE, já que em virtude da diplomação cassada não ter atingido mais de $50 \%$ dos votos válidos, são eles que auferirão a nova diplomação (...). (...).

20. A Impetrada em evidente arremedo de interpretação quer equiparar a situação especial, de direito especial, de jurisdição especializada, como são os problemas de indole eleitoral, da justiça eleitoral, de diplomação, do Direito Eleitoral, com problemas de Direito Constitucional comum: perda, extinção e suspensão de mandato são de competência da Câmara de Vereadores, sendo conheciveis na justiça comum; cassação de registro de candidaturas e de diplomas, aplicação de sanções de inelegibilidades, são problemas de estrita e indelegável competência da Justiça Eleitoral.

(...).

22. (...). Dessas lições resultam a diferença do caso presente, montado sobre o Direito Eleitoral, com o caso que deseja forcejar a Impetrada, arrimado, indevidamente, sobre as regras jurídicas que definem a linha sucessória em caso de vacância, por extinção de mandato (...)..

(...).

24. Da exegese (...) resta claro a distinção temporal e funcional entre diploma e mandato, sendo o diploma pressuposto lógico e jurídico do mandato: sem o diploma, o eleito não tomará posse, conseqüentemente não se investirá de mandato, não poderá exercer o cargo de mandatário popular. O diploma é de conferimento pela Justiça Eleitoral, e legitima o eleito para que a Câmara de Vereadores the dê posse.

$(\ldots)$.

31. No caso presente o acórdão do TSE fixou diretamente duas penas, e reflexamente um direito: diretamente multa e cassação de diploma de S., e reflexamente o direito à diplomação de A. e J.

(...).

33. Diante disso, ressalta, sem dúvida, a impropriedade da renúncia de $\mathrm{S}$. para os ilegítimos fins buscados pela Impetrada: realizar eleição indireta para escolha de Prefeito e Vice entre seus pares, quando deverá a justiça eleitoral decidir se os Impetrantes serão diplomados em segundo lugar, ou o povo de I. irá novamente às urnas escolher pelo sufrágio direto seus mandatários legítimos.

MM. Juízo, não existe a terceira hipótese, forçada pela Ré deste Writ! Ou novos diplomas por este r. Juízo aos Impetrantes ou nova eleição direta pelo povo de I.! É fraudar a lei buscar eleição indireta fundada em cassação de diploma!

(...).

36. Diante de todas as razóes expostas, concluí-se que: a) a cassação de diploma difere da hipótese de extinção de mandato; b) a renúncia de S. (titular do cargo de Prefeito - seguida ao falecimento do vice-prefeito) não pode obstar o direito dos Impetrantes de serem diplomados em segundo lugar, e assumirem seus postos de Prefeito e Vice; c) a execução do julgado do TSE se dará pela justiça eleitoral, na forma que esta definir, e não pelo arbítrio e sede de poder injurídico dos integrantes da Impetrada; d) o processo sucessório desencadeado pela Impetrada no dia de ontem e a consumar-se no próximo domingo, dia 15, é usurpante da competência da justiça eleitoral, violador do devido processo eleitoral dos Impetrantes, e coarcta ilegalmente seus direitos subjetivos públicos à diplomação, à posse e ao conseqüente exercício de seus mandatos."

No passado, a jurisprudência do TSE era acorde com esse entendimento: “[...] Vacância. Arts. 80 e 81 da CF. Inaplicabilidade. Aplica-se o art. 224 do CE quando a anulação superar 50\% dos votos [...] A eleição indireta prevista nos arts. 80 e 81 da Constituição Federal pressupóe a vacância por causa não eleitoral. [...]" NE: "O referido art. 81 da CF objetiva regular a substituição do chefe do Poder Executivo quando ocorre a vacância do cargo durante o mandato, por causa não eleitoral, quais sejam: falecimento, renúncia, desincompatibilização, além de cassação do mandato por ato do Poder Legislativo. [...] Na hipótese tratada, a vacância decorre de decisão oriunda da Justiça Eleitoral: o prefeito e o vice tiveram cassados os diplomas, dada a caracterização de captação ilícita de sufrágio."(Ac. de 9.3.2006, no AgRgMS no 3.427, rel. Min. Humberto Gomes de Barros.) 
Em suma, a preocupação contramajoritária no âmbito da justiça eleitoral nos faz refletir sobre o real prestígio e valor que conferimos, entre nós, às “vontades populares", à constitucional e sacra soberania popular.

E em nosso sistema jurídico, calha lembrar, temos muitas vontades referidas como de origem popular, que recebem, cada qual, uma específica proteção normativa.

Temos a vontade constituinte, cristalizada na Constituição; a vontade do legislador, produto da ação de representantes eleitos pelo colégio eleitoral; a vontade fruto da participação popular, no âmbito da chamada democracia participativa ${ }^{35}$, na qual se inserem a iniciativa popular das leis, plebiscito e referendo, etc; e a sacra vontade das urnas, a vontade expressão da soberania popular como prática e como princípio constitucional realizado no âmbito do sistema eleitoral.

O Judiciário eleitoral, manifestando a sua vontade judicial, deve, sobretudo, proteger a última vontade, a das urnas, com respeito extremo pela vontade constituinte, expressa na Constituição. Qualquer outra vontade, seja do legislador ou dos juizes, ou da iniciativa popular, que se contraponha à primeira, estará se impondo em detrimento da segunda, e será vontade ilegítima e inconstitucional.

Não obstante essa preocupação, o Judiciário eleitoral, coonestado pela Suprema Corte brasileira, como demonstra o caso de validade constitucional em torno da lei complementar 135/10 (lei da ficha limpa) , fez ${ }^{36}$ preponderar a "vontade da lei" e a "vontade judicial" em face da vontade popular das urnas. ${ }^{37}$ Essa lei reforçou o "braço de estivador" (Chico Buarque) da justiça eleitoral sobre a soberania popular. Ampliou desmedidamente a ação da justiça eleitoral em "tutela paternalista" da vontade popular. Radicalizou a judicialização das eleições e o seu produto - a vontade das urnas.

Hoje, em face do crescente processo de infantilização do eleitor, marginalização dos candidatos, e protagonização do processo eleitoral não mais pelo eleitor popular, mas pelo juiz eleitoral, é necessário investir mais em advogados do que em "marqueteiros", pois é muito provável que o resultado obtido nas urnas poderá ser "subvertido" ou "golpeado" na justiça eleitoral, em desfavor do eleito pela soberania popular e, principalmente, em desfavor da própria soberania popular ao argumento fictício de protegê-la dela própria!

35. Sobre o tema indicamos trabalho de nosso autoria: Ruy Samuel Espíndola. Democracia Participativa: auto-convocação de referendos e plebiscitos pela população (análise do caso brasileiro). Revista de Direito Constitucional e Internacional. Cadernos de Direito Constitucional e Ciência Política. São Paulo: Revista dos Tribunais/Instituto Brasileiro de Direito Constitucional, ano 19, abr./jun. 2011, n. 75, p. 335/355.

36. Lei que obteve reconhecimento constitucionalidade, quanto as suas hipóteses de inelegibilidades, nas ações diretas de constitucionalidade números 29 e 30, no STF, sob relatoria do Ministro Luiz Fux.

37. Não retomaremos aqui a discussão já sedimentada no STF, por maioria de votos. Apenas reportamos o que produzimos a respeito, revelando, ao nosso entender, o que haveria de inconstitucional na referida lei: ESPÍN-

DOLA, Ruy Samuel. A Lei Ficha Limpa em revista e os empates no STF. O dilema entre o politicamente correto e o constitucionalmente sustentável. Jus Navigandi, Teresina, ano 15, n. 2711, 3 dez. 2010. Disponível em: <http://jus.uol.com.br/revista/texto/17925>. Acesso em: 1 maio 2011; -.-. STF, insegurança jurídica e eleiçóes em 2012: Até quando o embate entre moralistas e constitucionalistas em torno da lei ficha limpa? Jus Navigandi, Teresina, ano 16, n. 2827, 29 mar. 2011. Disponível em: <http://jus.uol.com.br/revista/ texto/18790 >. Acesso em: 2 maio 2011; -.-. Lei Ficha Limpa estadual e limites constitucionais de sua produção legislativa. Análise da inacessibilidade a cargos em comissão por condenados por improbidade administrativa sem trânsito em julgado: 0 caso da lei catarinense. Jus Navigandi, Teresina, ano 16, n. 3051, 8 nov. 2011. Disponível em: <http://jus.com.br/revista/texto/20385>. Acesso em: 8 nov. 2011. 
Estamos a aplaudir, irrefletidamente, leis e interpretações judiciais que colocam a vontade popular sob a tutela judicial, como se o colégio eleitoral fosse composto por um conjunto de infantes que necessitam de intervenção "paternal" judiciária. Aí está o aplauso ao ideário ficha limpa como; também a concepção de contas eleitorais desaprovadas (o ideário "contas sujas"), ainda que sem a lei prevendo, apenas o TSE assim interpretando, poderia levar a não expedição de certidão eleitoral de quitação, consequentemente, à inelegibilidade do candidato, como dissemos.

Para evitarmos esses equívocos lógicos e teóricos, que abastecem hermenêuticas contra constitutione, é necessário não deslembrarmos que em Direito, notadamente em Direito Constitucional e Direito Eleitoral, há diferença entre a vontade das urnas, expressão imediata e soberana da vontade popular, vontade delegante, da vontade da democracia representativa, da vontade dos representantes eleitos pelos representados-cidadãos-eleitores. A vontade das urnas é pressuposto validatório e legitimador da vontade dos representantes. Sem a vontade das urnas, em nossa democracia, não pode haver a vontade do legislador representante.

A vontade popular, nas urnas, não é só pressuposto do Estado democrático de direito, é seu fim, sua base, é uma de suas maiores e mais sentidas preocupações. A vontade popular das urnas é mola, é propulsão, é legitimação de todo o sistema republicano e democrático fulcrado na Constituição.

Confundir a vontade dos representantes - a lei - com vontade dos representados - expressão da soberania popular -, colocando ambas em igual posição, é desconhecer a relação entre antecedente e conseqüente, entre poder delegante e poder delegatário, entre vontade constitucional e vontade constituída, entre vontade legitimante e vontade legitimada, entre democracia direta e democracia indireta, entre vontade autorizante e vontade autorizada, entre a vontade popular direta e a vontade da lei que deve resguardar e atender a soberania popular.

Essa confusão está legitimando que a Justiça eleitoral brasileira, muitas vezes, desprezando hermenêuticas prestigiadoras da máxima efetividade da soberania popular e dos princípios liberais republicanos ${ }^{38}$, passe a cassar registros, diplomas, mandatos, em "autocrática" exegese que sobrepuja a vontade das urnas com a inconstitucional vontade dos representantes, com a vontade da lei violadora da vontade de constituição (Konrad Hess e Friederich Muller)!

Esse raciocínio que confunde, mistura, iguala vontade das urnas e vontade dos representantes, que se baseia em pressuposições que derruem a primeira em face da segunda, é moldado no pré-conceito de que a vontade popular das urnas é menor do que a vontade da lei; que a vontade popular, imatura e frágil como a vontade de uma criança, de um interdito ou de um curatelado, não tem a força, a independência, a liberdade de um sujeito dotado de direitos, precisando da tutela, da curatela, da interdição, por vezes autoritária, da Justiça eleitoral, que no aparente conflito entre uma e outra, não tem, nos últimos tempos (caso emblemático do tema ficha limpa), se contido em interditar, em anular a primeira, na pressuposição de que a segunda é mais digna de crédito, é mais legítima, é mais eficaz, é mais forte, é mais consentânea ao anseio popular. ${ }^{39}$

38. Notadamente, realizando hermenêuticas que desprestigiam os direitos políticos fundamentais de candidatura, colocando o conceito de inelegibilidade e condiçóes de elegibilidade, como concretizantes deste, como "meros requisitos" para obtenção futura de postos eletivos. Dizendo que a privação de seu exercício, por inelegibilidade, "não seria pena”, etc.

39. No sentido de nossa crítica, ver Néviton de Oliveira Batista Guedes:

“Quem bem observar o Direito Eleitoral em nosso país irá concluir que, por trás de uma retórica de sacrali- 
Assim, sem uma doutrina da autocontenção e da heterocontenção da atuação da justiça eleitoral em sua função contramajoritária, quem protegerá a vontade popular da interdição, da curatela, da tutoria, algumas vezes autoritária e autocrática da Justiça eleitoral, que tem elegido como a mais importante a vontade da lei em detrimento da vontade popular, mesmo quando a lei tem sido acusada de inconstitucionalidades formal e material, quando a vontade constituída do legislador eleitoral tem sido questionada por malferir, por trair e violar a vontade constituinte?

De que lado, historicamente, deve ficar a Justiça eleitoral brasileira: da vontade popular manifestada nas urnas, da vontade constituinte expressa na Constituição ou da vontade da lei manifestada pelos representantes do povo? Qual a finalidade histórica desta justiça, senão guarnecer a vontade das urnas atendendo a vontade constituinte? Pode a justiça eleitoral desprezar a vontade popular direta das urnas em homenagem a vontade dos representantes contestada em face da vontade constituinte, cujo titular imediato é o povo?

Em nossa democracia constitucional, nossa opinião pública e nossos juízes eleitorais, devem refletir a fundo sobre todas essas questóes, tanto de lege lata, quando de lege ferenda.

É necessário tanto reformas na postura hermenêutica reinante no judiciário eleitoral, que deve passar a contabilizar, com mais cuidado, vagar e preocupação o valor jurídico de garantia

zação do eleitor, o que se vem verificando desde sempre é uma enorme desconfiança com a sua capacidade de proceder à melhor escolha possível. Essa desconfiança, por óbvio, não se pode manifestar abertamente por autoridades públicas, porquanto absolutamente contrária aos desígnios da nossa democrática Constituição de 1988. Mas, fora dos acontecimentos oficiais, escuta-se aqui e ali que uma intervenção judicial nas eleições é benéfica para o Brasil, pois o eleitor não sabe votar.

Outras formas de poder (teocracia, monarquia, aristocracia, ditadura) prometem exercer o domínio através de indivíduos especialmente qualificados (santos, homens ungidos por Deus, guerreiros, sábios e outros indivíduos com qualidades da mesma extraordinária estatura). A democracia não. Ela se contenta e promete exercer o poder através do "ordinary man", ou seja, seu funcionamento baseia-se na intelectualidade e na moral do homem comum, ou no dizer, de Ulrich Preu $\boldsymbol{\beta}$, a democracia, diversamente dos demais sistemas de domínio, sustenta humildemente o seu funcionamento na mediocridade do ser humano (Durchschnittlichkeit der menschen).

A democracia, ao contrário, pressupõe a humildade de confiar o poder, como já se disse, à Sua Excelência, ao eleitor, ou seja, ao cidadão comum. Nela, certamente, todos também têm a expectativa de que, ao final, o poder seja entregue aos melhores capacitados na sociedade, mas isso não é o fundamental para que a escolha seja considerada funcional no regime democrático. O que importa é que, disputando-se as eleições com máximo de igualdade e liberdade, os cidadãos, os homens comuns, em sua maioria, tenham a palavra final.

Aqueles que buscam e esperam, com a institucionalização de filtros e controles cada vez mais sofisticados, a segurança de que a democracia ou qualquer outro regime possa oferecer a certeza dos melhores, desconhecem a natureza das instituições humanas.

Nenhuma instituição humana pode pretender a perfeição do governo das coisas e dos homens. Ninguém o conseguiu: nem o partido único do regime burocrático - socialista, nem o Reich dos mil anos de Hitler , nem o rei filósofo de Platão. Suspeito que o Poder Judiciário, no Brasil, também não o conseguirá.

Aliás, onde essa ideia de perfeição e pureza nos negócios humanos foi levada muito a sério desaguou-se em ditaduras e totalitarismo. Na sua esplêndida obra, A sociedade aberta e seus inimigos, a tônica de Karl Popper é a de demonstrar que todo aquele que, cuidando de organizar o poder, anuncia a perfeição na terra dos homens acaba entregando autocracia ou totalitarismo de algum gênero." Em seu As eleiçóes municipais e o processo de democracia, Revista Consultor Jurídico, 17 de setembro de 2012, coluna "Constituição e Poder". 
ao direito político fundamental de candidatura ${ }^{40}$, quanto reformas na legislação eleitoral, que preservem com mais efetividade esse direito assim como assegure maior potência, estabilidade e eficácia do quanto decidido pelas urnas populares, que retratam outro sacro direito político fundamental: o de voto.

Este ensaio, sem querer esgotar todos os aspectos que a temática tratada poderia suscitar, apenas procurou trazer ao Direito Eleitoral brasileiro proposições que estudiosos e operadores do direito em geral, deverão enfrentar em tempos fichalimpistas, em tempos de elevado moralismo eleitoral que, no dizer de Adriano da Costa Soares ${ }^{41}$, as vezes, sem o confessar,

40. Isso ocorreu recentemente com o tema do prefeito itinerante, que recebeu adequada resposta protetiva não só à segurança jurídica, quanto à vontade popular, em decisão do STF de 01.08.12, tomada no Recurso Extraordinário 637.485. Ver, para tal, o artigo de MENDES, Gilmar Ferreira. Segurança jurídica e mudança na jurisprudência eleitoral, publicado em 18 de agosto de 2008, na Revista eletrônica Consultor Jurídico.

41. A noção crítica de moralismo eleitoral tem sido desenvolvida pelo eleitoralista Adriano da Costa Soares. O seu blog está repleto de excertos elucidativos. Vejamos:

I - "Já há algum tempo tenho chamado a atenção para o que denominei de "moralismo eleitoral”, um fenômeno perigoso que tem invadido a cidadela da jurisprudência eleitoral. (...). O moralismo eleitoral transforma todos os debates jurídicos eleitorais em debates morais e - o que é tanto pior! - sempre no compromisso de interditar o mais que possível que os políticos sejam... políticos. Há sempre um sentimento embutido nessa lógica: entrou na política, bandido é. E, na ânsia de higienização da política, deseja-se acabar com os políticos, o que nada mais é do que selar o fim da própria democracia. E, nessa concepção de mundo, esqueceram de um pequeno detalhe: o expurgo a ser feito deveria ser através do voto, salvo em casos extremos de crimes adrede positivados. Mais, em uma era da entronização acrítica do "fichalimpismo", o moralismo eleitoral reina absoluto, sem compromisso nenhum com o direito positivo vigente. É a justiça de mão própria togada, armada do direito achado na rua..." ver post de 2 de março de 2012 intitulado "Quitação eleitoral e hipermoralização do direito: na era do 'fichalimpismo“". -

II - "Trata-se de uma marcha insana de muitos em defesa do moralismo eleitoral, para a instauração de uma democracia sem votos, sem eleitor. Uma visão ingênua, casuística, em certo sentido reacionária. É a tentativa de construção de uma democracia tutelada, ao fim e ao cabo, de uma democracia sem previsibilidade, em que a segurança jurídica é um mal a ser combatido, em que as garantias individuais não passam de um estorvo pequeno burguês." "É isso, afinal, do que se trata: o moralismo eleitoral não respeita a Constituição Federal nem o ordenamento jurídico. Em nome da ética na política, às favas com os escrúpulos...." Ver post de 8 de junho de 2010 intitulado "Sandra Cureau e o Moralismo Eleitoral: as garantias individuais flexibilizadas." -

III - "Tenho combatido o que passei a denominar de moralismo eleitoral, ou seja, a adulteração da interpretação das normas jurídicas eleitorais pela aplicação de critérios acentuadamente morais, muitas vezes em aberta divergência com o próprio ordenamento jurídico posto. Em nome de princípios defendidos por determinadas minorias (ou mesmo maiorias, pouco importa) afasta-se a aplicação de determinada norma jurídica positivada, recriando antidemocraticamente o próprio ordenamento jurídico, sem observar os meios próprios para tanto. (...). Esse fenômeno crescente de, a partir de uma leitura principiológica da Constituição, enfraquecimento da própria positividade das normas infraconstitucionais ao ponto limite de deixarem elas de ser vinculativas para o aplicador, passou a ser sentido de modo alarmante na leitura que vem se fazendo de relevantes questões eleitorais (...)."“ (...). moralismo eleitoral parte normalmente de uma compreensão equivocada da teoria da inelegibilidade, que se póe a serviço de um certo justiçamento antidemocrático, ainda que movido pelas melhores intenções. Não há dúvidas que é necessário depurarmos as nossas instituições, porém essa é uma tarefa complexa, que não se esgota em medidas irrefletidas, movidas por um certo voluntarismo, que de tanto simplificar os problemas apenas cria novos problemas." ver post de 25 de dezembro de 2009 , intitulado "Moralismo Eleitoral, Inelegibilidade e Vida Pregressa." -

IV - “Ora, em uma democracia, quem deve afastar o mau político é o eleitor pelo voto. O critério de definição? Cabe ao eleitor definir. Porém, essa minoria não acredita na democracia, não acredita no eleitor: prefere, então, criar critérios de exclusão previamente. Antidemocraticamente. (...). Ah, mas o eleitor é 
apregoa uma democracia sem voto, sem eleitor, sem soberania popular, satisfeito com as escolhas autocráticas do Judiciário eleitoral, no exercício acrítico e por vezes periclitante de sua função contramajoritária.

analfabeto, dirão alguns. Ah, mas o eleitor vende o voto, dirão outros. Certo, então proibamos o pobre e o analfabeto de votar. Quem terá coragem de abertamente defender essa tese absurda? Ninguém, por evidente. Então, fingem defender a democracia, quando na verdade pretendem é criar, às avessas, uma espécie de sufrágio censitário. O eleitor vai votar, é certo, mas em uma lista antes já submetida a um processo de bigienização ideológica. A isso chamo de moralismo eleitoral, essa forma fundamentalista de aplicação de uma certa moral ao processo eletivo." ver post de 30 de junho de 2010, intitulado "Entrevista a um Blogueiro: Cidadania, Democracia e Fichas Limpas". -

V - "Mas o bipermoralismo eleitoral não quer saber o que é juridicamente sustentável ou não; interessa a sua sanha macartista, ainda que a Constituição seja desrespeitada. Este é o ponto: estamos sempre criando atalhos para sustentar essas normas inconstitucionais, mas com apelo popular, conferindo, assim, ao ordenamento jurídico um tratamento bizarro, sem pé nem cabeça, alimentando a insegurança jurídica. É disso que se trata. A mim me parece que não podemos negociar a aplicação adequada da Constituição; devem-se evitar soluções casuísticas que, ao final, se voltarão contra a própria sociedade." Ver post de 6 de julbo de 2010, intitulado "A parte final da minha entrevista a Yuri Brandão."

\section{s.}

ballot Rio de Janeiro, V. 1 N. 1, Maio/Agosto 2015, pp. 270-292 
Recebido em: 26/02/2015

Aceito em: 13/03/2015

\section{Como citar}

ESPÍNDOLA, Ruy Samuel. Justiça Eleitoral Contramajoritária e

Soberania Popular: a democrática vontade das urnas e a autocrática vontade judicial que a nulifica. Ballot. Rio de Janeiro: UERJ. Volume 1 Número 1 Junho 2015. pp. 270-292. Disponível em: [http://www.epublicacoes.uerj.br/index.php/ballot]

\section{cc) (1) (2)}

A Revista Ballot está licenciada sob uma licença Creative Commons Atribuição - Não Comercial - Compartilha Igual 3.0 Não Adaptada. 